\title{
PENGGUNAAN MODEL CREATIVE PROBLEM SOLVING UNTUK MENINGKATKAN PRESTASI BELAJAR BAHASA BALI SISWA KELAS X.IPA 8 SMA NEGERI 1 KUTA
}

\section{USING THE CREATIVE PROBLEM SOLVING MODEL TO IMPROVE BALI LEARNING ACHIEVEMENT STUDENTS OF CLASS X.IPA 8 SMA NEGERI 1 KUTA}

\author{
I Nengah Parwata* \\ SMA Negeri 1 Kuta, Badung, Bali, Indonesia \\ *Email Penulis korespondensi: kutaparwata@gmail.com
}

\begin{abstract}
Abstrak
Perolehan data prestasi belajar Bahasa Bali yang rendah bagi siswa di kelas X.IPA 8 di SMA Negeri 1 Kuta menuntun peneliti untuk melakukan penelitian tindakan, mengingat penelitian dilakukan di kelas maka penelitian ini disebut penelitian tindakan kelas. Penelitian ini bertujuan untuk mengeahui peningkatan prestasi belajar Bahasa Bali siswa. Dalam pelaksanaannya di lapangan, peneliti memberikan tahapan berupa siklus yang masing-masing tediri dari tahap perencanaan, tahap pelaksanaan, tahap observasi/pengumpulan data diakhiri dengan tahap refleksi yang termasuk melakukan analisis terhadap data yang sudah diperoleh.Setelah data dikumpulkan melalui tes dan dianalisis menggunakan analisis deskriptif diperoleh peningkatan hasil yang sesuai harapan tujuan penelitian ini. Data tersebut adalah peningkatan yang terjadi dari awal dimana siswa baru mampu mencapai ketuntasan belajar $44,44 \%$ dengan rata-rata kelas 66,94 dan pada siklus I telah meningkat ketuntasan belajar menjadi $75 \%$ dengan rata-rata kelas 69,86 dan pada siklus II sudah meningkat sesuai harapan yaitu ketuntasan mereka sudah mencapai $100 \%$ dengan rata-rata kelas 81,22 . Sedangkan indikator keberhasilan penelitian pada siklus II membuat agar prosentase ketuntasan belajar mereka mencapai minimal 85\% dengan rata-rata kelas 80,00. Sedangkan data yang diperoleh sudah melebihi indikator tersebut. Oleh karenanya peneliti berkesimpulan bahwa penerapan Creative Problem Solving dalam proses belajar mengajar mampu meningkatan belajar Bahasa Bali siswa.
\end{abstract}

Kata-Kata Kunci: Model Pembelajaran Creative Problem Solving; Prestasi Belajar

\begin{abstract}
The acquisition of data on learning achievement in Balinese is low for students in class X.IPA 8 at SMA Negeri 1 Kuta leading researchers to conduct action research, considering that research is carried out in class, this research is called classroom action research. This study aims to determine the improvement of students' learning achievement in Balinese. In its implementation in the field, the researcher provides stages in the form of a cycle, each of which consists of the planning stage, implementation stage, observation/data collection stage ending with a reflection stage which includes analyzing the data that has been obtained. After the data is collected through tests and analyzed using analysis descriptively, the results obtained are in line with the expectations of the objectives of this study. The data is an increase that occurred from the beginning where new students were able to achieve learning completeness of $44.44 \%$ with a class average of 66.94 and in the first cycle, learning mastery had increased to $75 \%$ with an average grade of 69.86 and in the second cycle has increased as expected, namely their completeness has reached $100 \%$ with a class average of 81.22 . While the indicators of research success in the second cycle make the percentage of their learning completeness reach a minimum of $85 \%$ with a class average of 80.00. While the data obtained has exceeded these indicators. Therefore, the researcher concludes that the application of Creative Problem Solving in the teaching and learning process is able to improve students' Balinese language learning.
\end{abstract}

Keywords: Creative Problem Solving Learning Model; Learning Achievement 


\section{PENDAHULUAN}

Depdiknas (2013:5) juga menjabarkan aturan yang jelas untuk mencapai tujuan pembelajaran yang diharapkan,yaitu dengan mengembangkan proses belajar yang menyenangkan, memperhatikan keinginan siswa, membangun pengetahuan dari apa yang diketahui siswa, menciptakan suasana kelas yang mendukung kegiatan belajar, memberikan kegiatan yang sesuai dengan tujuan pembelajaran, memberikan kegiatan yang menantang, memberikan kegiatan yang memberi harapan keberhasilan, menghargai setiap pencapaian siswa.

Dalam meyakinkan bahwa guru sebagai pekerjaan professional, marilah kita tinjau syarat-syarat atau ciri pokok dari pekerjaan profesional. (a) Pekerjaan profesional ditunjang oleh suatu ilmu tertentu secara mendalam yang hanya mungkin didapatkan dari lembagalembaga pen $\neg$ didikan yang sesuai, sehingga kinerjanya didasarkan kepada keilmuanyang dimilikinya yang dapat dipertanggungjawabkan secara ilmiah. (b) Suatu profesi menekankan kepada suatu keahlian dalam bidang ter $\neg$ tentu yang spesifik sesuai dengan jenis profesinya, sehingga antaraprofesi yang satu dengan yang lainnya dapat dipisahkan secara tegas. (c) Tingkat kemampuan dan keahlian suatu profesi didasarkan kepadalatar belakang pendidikan yang dialaminya yang diakui oleh masya $\neg$ rakat, sehingga semakin tinggi latar belakang pendidikan akademis sesuai dengan profesinya, semakin tinggi pula tingkat keahliannyadengan demikian semakin tinggi pula tingkat penghargaan yangditerimanya. (d) Suatu profesi selain dibutuhkan oleh masyarakat juga memiliki dampak terhadap sosial kemasyarakatan, sehingga masyarakat memilikikepekaan yang sangat tinggi terhadap setiap efek yang ditimbulkannyadari pekerjaan profesinya itu (Sanjaya, Wina, 2016: 275).

Untuk menghadapi tantangan zaman dengan kemajuan teknologi informasi dan ilmu pengetahuan yang serba cepat dibutuhkan guru profesional yang intelektual dan bermoral. Sosok guru yang mampu memunculkan inovasi dalam pendidikan adalah guru yang menurutnya mau terus berkembang dan belajar seumur hidup, tidak pernah puas dengan apa yang dimengerti, mau membawa perubahan, berpikir kritis, rasional bebas mengembangkan pikiran, reflektif, berani membela kebenaran dan keadilan. Dan tidak dibutuhkan guru yang hanya mempertahankan status quo-nya dan menjalankan tugasnya seperti tukang (Idrus, 2015: 157).

Menyadari permasalahan yang sedang dihadapi, untuk mendukung semua yang telah dijelaskan di atas. Guru selaku peneliti yang bertugas di SMA Negeri 1 Kuta mencoba melakukan koreksi dan refleksi atas hasil belajar awal siswa kelas X.IPA 8 semester II Tahun pelaajaran 2019/2020 yang ditemukan pada saat observasi. Rata-rata nilai mata pelajaran Bahasa Bali siswa yang diperoleh hanya mencapai 66,94 dengan prosentase ketuntasan belajar sebesar $44,44 \%$. Nilai tersebut ternyata masih jauh dari Kriteria Ketuntasan Minimal (KKM) yang ditetapkan sekolah sebesar 70,00.

Pengamatan dan perenungan kembali jalannya proses pembelajaran yang telah dilakukan membuahkan kesimpulan beberapa faktor yang penyebabnya adalah (a) kurang seriusnya guru dalam melakukan persiapan untuk memulai proses pembelajaran; (b) kurangnya daya dukung berupa media/sumber belajar yang dimanfaatkan guru saat pelaksanaan pembelajaran, dan (c) kurangnya daya kreativitas siswa akibat waktu belajar banyak dikuasai guru sehingga ketika usai proses pembelajaran pengetahuan dan pemahaman yang harusnya dikuasai siswa belum tecapai.

Mempertimbangkan kondisi tersebut, guru melakukan konsultasi dengan beberapa teman sejawat dan ditemukan solusi yang menurut pertimbangan guru akan mampu menuntaskan permasalahan yang sedang dihadapi. Solusi tersebut adalah mengupayakan 
model pembelajaran berbasis masalah untuk melatih siswa agar dapat berpikir kreatif dan kritis menghadapi masalah.Dukunganyang disiapkan guru untuk mewujudkan hal itu dengan mengupayakan dan memanfaatkan media pembelajaran yang mampu menarik minat dan konsentrasi mereka untuk belajar. Hal itu dilakukan mempertimbangkan apa yang disampaikan Darmawan (2017: 66) yang mengkaji tentang media, model pembelajaran, dan perilaku belajar peserta didik, dengan pernyataan bahwa peranan teknologi informasi dan komunikasi dalam mengemas informasi pembelajaran akan memperkuat stimulus dalam proses pembelajaran. Dengan stimulus ini pembelajar akan mampu mengoptimalkan perilaku belajarnya.

Itu berarti, kuatnya stimulus yang diberikan guru berpengaruh sangat besar untuk memunculkan minat, motivasi, konsentrasi dan semangat belajar siswa. Dewasa ini, stimulus terkuat yang mampu mempengaruhi semua orang adalah multimedia komputer/laptop. Manfaat penggunaan multimedia dalam proses pembelajaran seperti komputer memiliki kemampuan yang luar biasa dibandingkan media lainnya, dan aplikasi software pembelajaran merupakan salah satu sumber belajar yang dirancang (learning resources by design) dimana di dalamnya telah disiapkan untuk tujuan pembelajaran tertentu.Media mutahir berbasis komputer yang diyakini mampu menciptakan pembelajaran yang lebih "hidup" dan dan melibatkan interaktifitas siswa (Buchori, 2012).

Dasar kajian inilah yang kemudian dijadikan landasan guru untuk melakukan pembuktian sendiri dalam proses pembelajaran yang dilakukan, sejauh mana model pembelajaran yang dilaksanakan secara kreatif dengan media pembelajaran yang bertumpu pada kemajuan teknologi informasi dapat meningkatkan prestasi belajar Bahasa Bali siswa.

Sehubungan dengan ketentuan penyusunan rumusan masalah yang pada dasarnya merupakan suatu pertanyaan dari kenyataan yang ada dan harapan yang diinginkan, maka masalah yang dapat peneliti rumuskan untuk penelitian ini adalah: Apakah memaksimalkan penerapan model pembelajaran Creative Problem Solving dapat meningkatkan prestasi belajar Bahasa Bali siswa kelas X.IPA 8 semester II SMA Negeri 1 Kuta tahun pelajaran 2019/2020? Tujuan penelitian merupakan landasan yang kuat dalam melanjutkan sebuah karya tulis ilimiah. Berdasarkan rumusan yang telah dibuat maka tujuannya dapat disampaikan yaitu: Untuk meningkatkan prestasi belajar Bahasa Bali siswa kelas X.IPA 8 semester II SMA Negeri 1 Kuta Tahun Pelajaran 2019/2020 dengan memaksimalkan model pembelajaran Creative Problem Solving dalam pembelajaran. Manfaat penelitian tindakan kelas adalah: 1) Bagi guru Bahasa Bali, dapat digunakan sebagai masukan dalam mengatasi kesulitan-kesulitan yang dialami siswa khususnya guru mata pelajaran. 2) Bagi siswa, terutama sebagai subjek penelitian, diharapkan dapat memperoleh pengalaman belajar yang lebih bervariasi dan menarik, kreatif, aktif, efektif dalam pembelajaran Bahasa Bali. 3) Bagi sekolah, dengan diterapkannya model-model pembelajaran yang baru yang dilaksanakan guru, secara tidak sadar peningkatan mutu pendidikan secara optimal akan lebih baik.

Model Pembelajaran Creative Problem Solving adalah suatu model pembelajaran yang melakukan pemusatan pada pengajaran dan keterampilan pemecahan masalah, yang diikuti dengan penguatan keterampilan. Ketika dihadapkan dengan suatu pertanyaan, siswa dapat melakukan keterampilan memecahkan masalah untuk memilih dan mengembangkan tanggapannya. Tidak hanya dengan cara menghafal tanpa dipikir, keterampilan memecahkan masalah memperluas proses berpikir. Adapun proses dari model pembelajaran CPS (Creative Problem Solving ), terdiri atas klarifikasi masalah, pengungkapan pendapat, evaluasi dan pemilihan, dan implementasi. Dengan membiasakan siswa menggunakan langkah-langkah yang kreatif dalam memecahkan masalah, diharapkan dapat membantu siswa untuk mengatasi kesulitan dalam belajar. Penggunaan model pembelajaran CPS ini diharapkan dapat menimbulkan minat sekaligus kreativitas dan motivasi siswa dalam mempelajari setiap 
materi pelajaran, sehingga siswa dapat memperoleh manfaat yang maksimal baik dari proses maupun hasil belajarnya (Supardi dan Putri, 2014).

Model Creative Problem Solving (CPS) pertamakali dikembangkan oleh Alex Osborn pendiri The Creative Education Foundation (CEF) dan co-founder of highly successful New York Advertising Agenncy. Pada tahun 1950-an Sidney Parnes bekerjasama dengan Alex Osborn melakukan penelitian untuk menyempurnakan model ini. Sehingga model Creative Problem Solvingini juga dikenal dengan nama The Osborn-parnes Creative Problem SolvingModels. Pada awalnya model ini digunakan oleh perusahaan-perusahaan dengan tujuan agar para karyawan memiliki kreativitas yang tinggi dalam setiap tanggungjawab pekerjaannya, namun pada perkembangan selanjutnya model ini juga diterapkan pada dunia pendidikan.

Wardani (2014: 60) menyebutkan bahwa langkah-langkah dalam memecahkan masalah adalah: 1) visualisasi masalah yaitu dengan mengidentifikasi pendekatan umum terhadap masalah, yakni konsep dan prinsip fisika yang paling tepat untuk masalah tersebut, 2) mendeskripsikan masalah dan deskripsi fisika yaitu dengan menandai secara simbolik variabel yang diketahui dan tidak diketahui yang kemudian menyatakan prinsip dan hubungan kuantitatif yang bersifat umum, 3) merencanakan solusi yang melibatkan siswa menterjemahkan deskripsi fisika ke dalam represtasi matematis yang tepat, 4) menyelesaikan rencana yakni siswa diharapkan dapat menghitung variabel target dengan mensubstitusikan nilai yang diberikan, 5) menilai atau mengevaluasi jawaban yaitu siswa hendaknya menanyakan kembali apakah jawaban diperoleh sudah benar dan lengkap. Pelaksanaan pembelajaran ini haruslah didukung dengan segala sesuatu yang menyentuh kebutuhan siswa untuk dapat menggali berbagai informasi yang sesuai dan diperlukan dalam memecahkan masalah, misalnya laboratorium, perpustakaan, LKS dan media pembelajaran yang relevan. Melalui langkah pembelajaran yang diungkapkan di atas, siswa dilatih mengembangkan kompetensi penalaran sehingga daya nalar dan kreativitas berpikir dapat berkembang yang pada akhirnya mereka berlatih berfikir secara logis, kritis dan kreatif.

Wardani (2014:58) menyebutkan ada beberapa hal yang perlu diperhatikan dalam pembelajaran pemecahan masalah yakni: 1) menentukan permasalahan yang akan disajikan disesuikan dengan materi, 2) masalah yang disajikan harus mampu mendorong siswa berpikir dari berbagai sudut pandang yang berbeda, 3) masalah harus disesuaikan dengan dengan tingkat kemampuan siswa, 4) masalah harus jelas, 5) masalah dikaitkan dengan dunia nyata dan cukup menarik siswa.

M. Nur (2013:45) mengatakan bahwa ciri kelas yang melaksanakan pembelajaran adalah: 1) siswa secara aktif terlibat dalam pembelajaran, 2) siswa belajar dari temannya melalui kerja kelompok, diskusi, saling mengkoreksi, 3) pembelajaran menekankan pada masalah bersifat terbuka, 4) prilaku siswa dibangun atas kesadaran diri dan hadiah untuk prilaku baik adalah kepuasan diri, 5) siswa menggunakan kemampuan berpikir kritis dan kreatif terlibat penuh dan ikut bertanggung jawab dalam mengayakan terjadinya proses pembelajaran yang efektif, 6) penghargaan terhadap pengakuan siswa sangat diharapkan.

Langkah-langkah dalam Creative Problem Solving (Rahman, 2017:10) adalah: a) Mess-finding (menemukan masalah yang dirasakan sebagai pengganggu). Tahap pertama, merupakan suatu usaha untuk mengidentifikasi situasi yang dirasakan mengganggu. b) Factfinding (menemukan fakta). Tahap kedua, mendaftar semua fakta yang diketahui yang berhubungan dengan situasi tersebut, yang dibutuhkan untuk mengidentifikasi informasi yang tidak diketahui tetapi esensial pada situsi yang sedang diidentifikasi dan dicari. c) Problemfinding (menemukan masalah). Pada tahap menemukan masalah, diupayakan mengidentifikasi semua kemungkinan pernyataan masalah dan kemudian memilih yang paling penting atau yang mendasari masalah. d) Idea-finding. Pada tahap ini diupayakan 
untuk menemukan sejumlah ide atau gagasan yang mungkin dapat digunakan untuk memecahkan masalah. e) Solution-finding. Pada tahap penemuan solusi, ide-ide atau gagasan-gagasan pemecahan masalah diseleksi, untuk menemukan ide yang paling tepat untuk memecahkan masalah. f) Acceptance-finding. Berusaha untuk memperoleh penerimaan atas solusi masalah, menyusun rencana tindakan dan mengimplementasikan solusi tersebut.

Proses pembelajaran dengan model pembelajaran Creative Problem Solving menurut Supardi (2014:574) terdiri dari langkah-langkah: 1) Klarifikasi Masalah. Klasifikasi masalah meliputi penjelasan mengenai masalah yang diajukan kepada siswa, agar siswa memahami penyelesaian seperti apa yang diharapkan. 2) Pengungkapan Pendapat. Pada tahap ini siswa diberi kebebasan untuk mengungkapkan pendapat tentang bagaimana macam strategi penyelesaian masalah. Dari setiap ide yang diungkapkan, siswa mampu untuk memberikan alasan. 3) Evaluasi dan Pemilihan. Pada tahap evaluasi dan pemilihan ini, setiap kelompok mendiskusikan pendapat-pendapat atau strategi mana yang cocok untuk menyelesaikan masalah 4) Implementasi (penguatan). Pada tahap ini siswa menentukan strategi mana yang dapat diambil untuk menyelesaikan masalah, kemudian menerapkanya sampai menemukan penyelesaian dari masalah tersebut. Selain itu, pada tahapan implementasi, siswa diberi permasalahan baru agar dapat memperkuat pengetahuan yang telah diperolehnya.

Prestasi belajar berasal dari kata "prestasi" dan "belajar". Prestasi berarti hasil yang telah dicapai sedangkan belajar adalah berusaha memperoleh kepandaian/ilmu (Depdiknas, 2013: 4).

Menurut Suryabrata (2016), mempunyai kesamaan dalam mengartikan prestasi belajar, yaitu hasil kecakapan atau kemampuan individu untuk menguasai sejumlah materi tertentu, program pelajaran yang diajarkan atau dipelajari, melalui usaha yang dilakukannya dalam proses belajar.

Menurut Sardiman (2013:20), belajar akan lebih baik apabila subyek belajar mengalami atau melakukannya, belajar dapat diartikan sebagai kegiatan psikofisik menuju keperkembangan pribadi seutuhnya. Belajar juga dapat diartikan sebagai usaha penguasaan materi ilmu pengetahuan yang sebagian bertujuan untuk membentuk kepribadian seutuhnya. Menurut Ngalim Purwanto (2011: 85), belajar merupakan suatu proses yang tidak dapat dilihat dengan nyata, proses itu terjadi di dalam diri seseorang yang mengalami belajar. Menurut Sugihartono (2017: 74), merupakan suatu proses memperoleh pengetahuan dan pengalaman dalam wujud perubahan tingkah laku dan kemampuan bereaksi yang relatif permanen atau menetap karena adanya interaksi individu dalam lingkungannya.

W.S. Winkel (2013:47) prestasi belajar adalah keberhasilan usaha yang dicapai seseorang setelah memperoleh pengalaman belajar atau mempelajari sesuatu. Dalam pembahasan sebelumnya telah dibicarakan bahwa prestasi belajar adalah hasil penilaian pendidikan tentang kemajuan prestasi siswa setelah melakukan aktivitas belajar. Ini berarti prestasi belajar tidak akan bisa diketahui tanpa dilakukan penilaian atas hasil aktivitas belajar siswa. Fungsi prestasi belajar bukan saja untuk mengetahui sejauhmana kemajuan siswa setelah menyelesaikan suatu aktivitas, tetapi yang lebih penting adalah sebagai alat untuk memotivasi setiap siswa agar lebih giat belajar,baik secara individu maupun kelompok. Dalam pembahasan ini akan dibicarakan mengenai prestasi belajar sebagai hasil penilaian dan pada pembahasan berikutnya akan dibicarakan pula prestasi belajar sebagai alat motivasi. Prestasi belajar sebagai hasil penilaian sudah dipahami.Namun demikian untuk mendapatkan pemahaman, perlu juga diketahui, bahwa penilaian adalah sebagai aktivitas dalam menentukan rendahnya prestasi belajar itu sendiri.

Slameto (2013: 22), mengatakan bahwa fungsi prestasi belajar adalah: (a) sebagai indikator dan kuantitas pengetahuan yang telah dimiliki oleh pelajar, (b) sebagai lambang pemenuhan keingintahuan, (c) informasi tentang prestasi belajar dapat menjadi perangsang 
untuk peningkatan ilmu pengetahuan dan (d) sebagai indikator daya serap dan kecerdasan murid.

Bila kita coba lihat lebih dalam dari pendapat di atas, maka prestasi belajar dipengaruhi banyak faktor.Faktor-faktor dari si pebelajar sendiri atau faktor dalam diri siswa dan faktor luar. Faktor dalam diri siswa seperti IQ, motivasi, etos belajar, bakat, keuletan,dan lain-lain sangat berpengaruh pada prestasi belajar siswa.

Menurut Slameto (2013: 2) bahwa belajar adalah suatu proses usaha yang dilakukan seseorang untuk memperoleh suatu perubahan tingkah laku yang baru secara keseluruhan, sebagai hasil pengalamannya sendiri dalam interaksi dengan lingkungannya. Secara sederhana dari pengertian belajar sebagaimana yang dikemukakan oleh pendapat di atas, dapat diambil suatu pemahaman tentang hakekat dari aktivitas belajar adalah suatu perubahan yang terjadi dalam diri individu. Prestasi belajar adalah hasil yang telah dicapai atau diperoleh siswa berupa nilai mata pelajaran. Ditambahkan bahwa prestasi belajar merupakan hasil yang mengakibatkan perubahan dalam diri individu sebagai hasil dari aktivitas dalam belajar.

Dari pendapat di atas dapat disimpulkan bahwa prestasi belajar adalah hasil usaha siswa yang dapat dicapai berupa penguasan pengetahuan, kemampuan kebiasaan dan keterampilan serta sikap setelah mengikuti proses pembelajaran yang dapat dibuktikan dengan hasil tes. Prestasi belajar merupakan suatu hal yang dibutuhkan siswa untuk mengetahui kemampuan yang diperolehnya dari suatu kegiatan yang disebut belajar.

\section{METODE PENELITIAN}

Yang digunakan sebagai tempat diadakan pelatihan tindakan kelas adalah SMA Negeri 1 Kuta. Sekolah ini lingkungannya bersih, aman, nyaman dan lestari. Seorang ahli yang bernama Arikunto, Suharsimi, 2017 peneliti ikuti sebagai pedoman pelaksanaan penelitian ini.

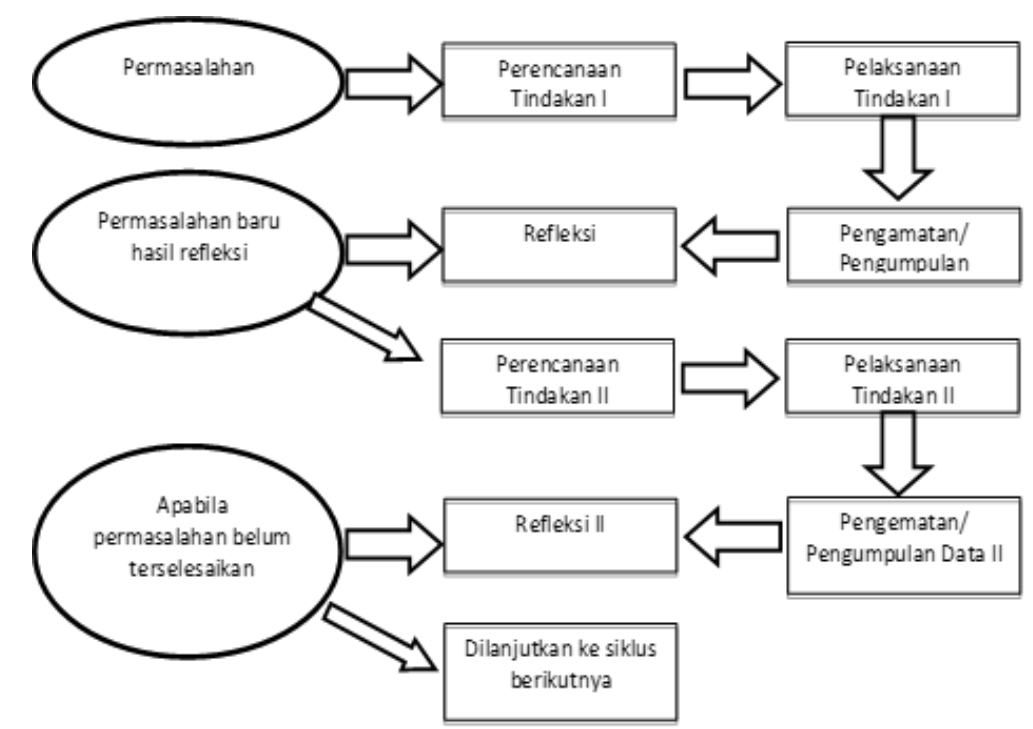

Gambar 1. Alur Penelitian Tindakan Kelas

Prosedur: Rancangan yang dibuat para ahli sangat penting dijadikan pedoman dalam melaksanakan penelitian. Prosedur pelaksanaannya tentu saja mengikuti alur rancangan para ahli. Dalam penelitian ini yang diikuti adalah rancangan atau gambar yang dibuat oleh Arikunto, Suharsimi, 2017, sehingga prosedur yang diikuti adalah mulai denganadanya suatu permasalahan. Setelah diketahui ada masalah, dibuat perencanaan, kemudian dilaksanakan, 
diamati dan dilakukan refleksi. Setelah refleksi akan terlihat permasalahan yang tersisa yang merupakan masalah baru. Dengan adanya masalah baru maka dibuat perencanaan ulang, dilaksanakan, diamati dan dilakukan refleksi. Bila permasalahan belum bisa diatasi maka dilanjutkan dengan siklus berikutnya.

Penentuan subjek penelitian ini terfokus pada adanya sebuah peningkatan dari prestasi belajar Bahasa Bali yang rendah sebelumnya untuk bisa ditingkatkan dalam pelaksanaan penelitian. Dalam penelitian ini mempergunakan subjek siswa kelas X.IPA 8 sebanyak 36 orang siswa. Objek penelitian adalah peningkatan prestasi belajar Bahasa Bali siswa kelas X.IPA 8 semester II SMA Negeri 1 Kuta tahun pelajaran 2019/2020 dengan memaksimalkan penerapan model creative problem solving. Bulan mulainya penelitian ini adalah Januari dan berakhirnya di bulan Mei tahun 2020. Hasil belajar yang diperoleh siswa setelah pelaksanaan tindakan didapat peneliti melalui tes prestasi belajar. Secara garis besar, teknik analisis data dapat dilakukan melalui dua cara, yaitu analisis data kualitatif dan kuantitatif. Sehubungan dengan data yang ingin diperoleh dalam penelitian ini berbentuk angka maka analisisnya dilakukan secara kuantitatif. Analisis kuantitatif dilakukan secara statistik sederhana dengan melakukan penyajian data, menghitung mean, median, modus, serta melakukan penggambaran secara rinci dalam bentuk tabel distribusi frekuensi dan grafik. Data yang diperoleh kemudian dideskripsikan untuk mendapatkan gambaran hasil penelitian yang diinginkan.

\section{HASIL DAN PEMBAHASAN}

Perolehan hasil dari penilaian yang telah dilakukan dapat diberi deskripsi: dari 36 orang siswa ada $13(36,11 \%)$ siswa yang memperoleh penilaian sesuai KKM dimana mereka sudah mampu menerima ilmu yang diberikan guru dengan baik. Ada $3(8,33 \%)$ yang memperoleh penilaian diatas KKM yang artinya mereka sudah mampu menerpa ilmu dengan sangat baik walaupun demikian masih ada 20 orang $(55,56 \%)$ yang belum mencapai KKM. Data tersebut menunjukkan bahwa perolehan perkembangan siswa belum sesuai indikator keberhasilan penelitian.

Tabel 1. Data Kelas Interval Siklus I

\begin{tabular}{ccccc}
\hline $\begin{array}{c}\text { No } \\
\text { Urut }\end{array}$ & Interval & $\begin{array}{c}\text { Nilai } \\
\text { Tepi }\end{array}$ & $\begin{array}{c}\text { Frekuensi } \\
\text { Absolut }\end{array}$ & $\begin{array}{c}\text { Frekuensi } \\
\text { Relatif }\end{array}$ \\
\hline 1 & $60-63$ & $59,5-63,5$ & 3 & 8,33 \\
2 & $64-67$ & $63,5-67,5$ & 6 & 16,67 \\
3 & $68-71$ & $67,5-71,5$ & 19 & 52,78 \\
4 & $72-75$ & $71,5-75,5$ & 5 & 13,89 \\
5 & $76-79$ & $75,5-79,5$ & 0 & 0,00 \\
6 & $80-83$ & $79,5-83,5$ & 3 & 8,33 \\
\hline & Total & & 36 & 100 \\
\hline
\end{tabular}

Pada siklus I analisis kuantitatifnya menggunakan data yang diperoleh adalah dalam bentuk angka sebagai berikut: Rata-rata (mean) dihitung dengan membagi nilai keseluruhan siswa dengan jumlah siswa, sehingga pada siklus I diperoleh rata-rata 2.515 dibagi 36 menjadi 69,86. Median (titik tengahnya) dicari dengan mengurut data/nilai siswa dari yang terkecil sampai terbesar. Setelah diurut apabila jumlah data ganjil maka mediannya adalah data yang ditengah. Kalau jumlahnya genap maka dua data yang di tengah dijumlahkan 
dibagi 2 (dua). Untuk median yang diperoleh dari data siklus I dengan menggunakan cara tersebut adalah: 70,00. Modus (angka yang paling banyak/paling sering muncul) setelah diasccending/diurut. Angka tersebut adalah: 70,00. Untuk persiapan penyajian dalam bentuk grafik maka hal-hal berikut dihitung terlebih dahulu. Banyak kelas $(K)=1+3,3 \times \log (N)=$ $1+3,3 \times \log 44=1+(3,3 \times 1,64)=1+5,41=6,41 \rightarrow 6$. Rentang kelas $(r)=$ skor maksimum - skor minimum $=85-70=15$. Panjang kelas interval $(\mathrm{i})=\frac{r}{K}=\frac{15}{6}=2,50 \rightarrow 3$.

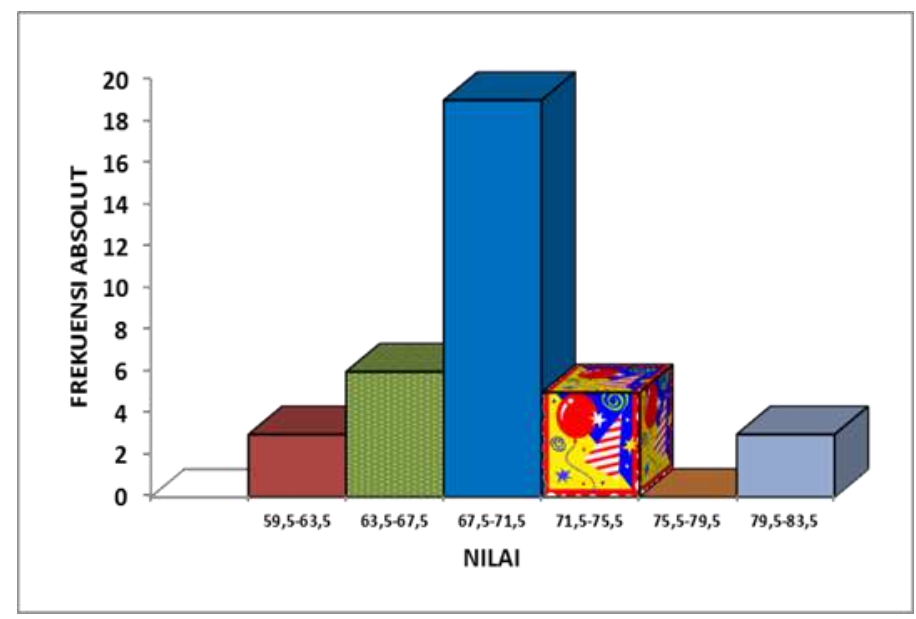

Gambar 2. Histogram Siklus I

Pada siklus II secara kualitatif hasil yang diperoleh dapat dijelaskan : dari 36 orang siswa yang diteliti ada $28(77,78 \%)$ siswa yang mendapat nilai diatas KKM artinya mereka sudah mampu menguasai materi-materi yang diberikan dan mereka sudah berkembang sangat baik melebihi indikator yang dituntut. Ada $8(22,22 \%)$ siswa yang mendapat nilai sama dengan rata-rata KKM yang artinya bahwa mereka sudah mampu walaupun kemampuannya baru pada tingkat batas minimal KKM. Apabila mereka mau meningkatkan prestasi belajar Bahasa Bali mereka lebih tinggi maka mereka harus lebih giat lagi, mereka sudah berkembang sesuai indikator. Setelah diberikan gambaran terhadap perolehan data secara kualitatif kemudian dilanjutkan dengan analisis kuantitatif seperti berikut: Banyak kelas $(\mathrm{K})=$ $1+3,3 \times \log (\mathrm{N})=1+3,3 \times \log 44=1+(3,3 \times 1,64)=1+5,41=6,41 \rightarrow 6$. Rentang kelas $(\mathrm{r})=$ skor maksimum - skor minimum $=90-79=11$. Panjang kelas interval $(\mathrm{i})=\frac{r}{k}=$ $\frac{11}{6}=1,8 \rightarrow 2$.

Tabel 2. Data Kelas Interval Siklus II

\begin{tabular}{ccccc}
\hline $\begin{array}{c}\text { No } \\
\text { Urut }\end{array}$ & Interval & $\begin{array}{c}\text { Nilai } \\
\text { Tepi }\end{array}$ & $\begin{array}{c}\text { Frekuensi } \\
\text { Absolut }\end{array}$ & $\begin{array}{c}\text { Frekuensi } \\
\text { Relatif }\end{array}$ \\
\hline 1 & $70-73$ & $69,5-73,5$ & 5 & 13,89 \\
2 & $74-77$ & $73,5-77,5$ & 3 & 8,33 \\
3 & $78-81$ & $77,5-81,5$ & 8 & 22,22 \\
4 & $82-85$ & $81,5-85,5$ & 17 & 47,22 \\
5 & $86-89$ & $85,5-89,5$ & 0 & 0,00 \\
6 & $90-93$ & $89,5-93,5$ & 3 & 8,33 \\
\hline & Total & & 36 & 100 \\
\hline
\end{tabular}




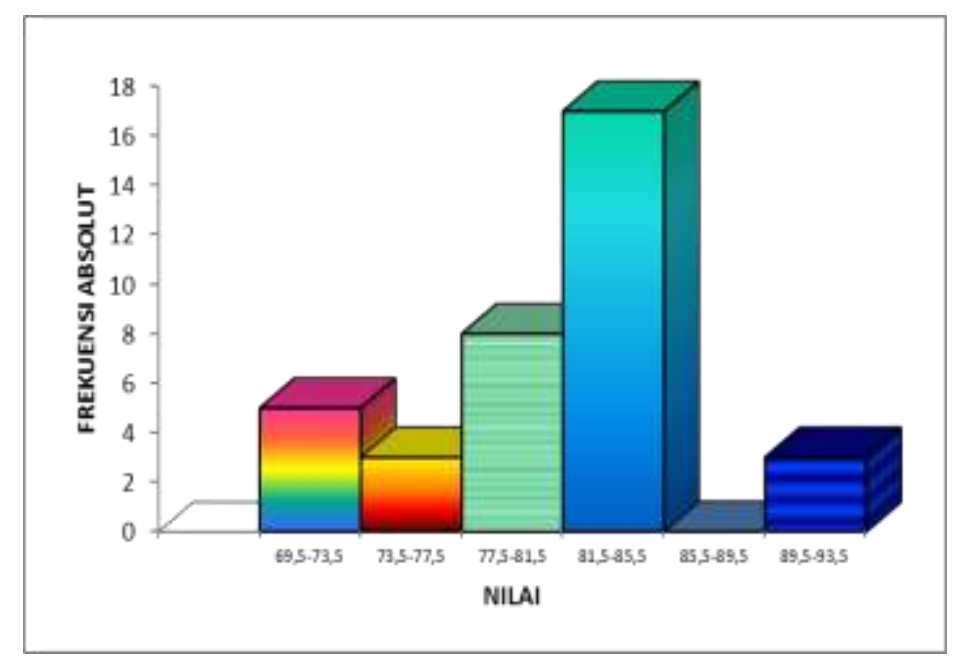

Gambar 3. Histogram Siklus II

Data awal menunjukkan rendahnya prestasi belajar Bahasa Bali siswa yang baru mencapai ketuntasan 44,44\%. Dari data tersebut banyak terjadi kelemahan-kelemahan atau kekurangan-kekurangan dalam pelaksanaan proses pembelajaran akibat cara pembelajaran yang dilakukan masih yang sehari-hari dilakukan tanpa mau melihat teori-teori baru.

Pada Siklus I diperoleh data dari pelaksanaan penelitian sudah ada 8,33\% siswa mencapai nilai di atas KKM, ada 66,67\% yang baru mencapai nilai rata-rata KKM dan $25 \%$ siswa yang masih tertinggal. Untuk data ini belum sesuai dengan harapan indikator keberhasilan penelitian yang dicanangkan yaitu lebih dari $80 \%$ siswa mampu mencapai keberhasilan sesuai KKM. Data yang diperoleh pada Siklus I ini menunjukkan persentase pencapaian peningkatan prestasi belajar Bahasa Balisiswa belum memenuhi harapan sesuai ketercapaian indikator keberhasilan penelitian sehingga penelitian ini masih perlu untuk dilanjutkan ke siklus berikutnya.

Pada Siklus ke II ini diperoleh data dari hasil penelitian yaitu 77,78\% siswa mampu mencapai tingkat perkembangan melebihi tuntutan indikator, ada 22,22\% siswa sudah mencapai tingkat keberhasilan sesuai tuntutan KKM keberhasilan penelitian atau sudah berkembang sesuai harapan. Dari semua data yang diperoleh, ternyata indikator keberhasilan penelitian yang menuntut $85 \%$ lebih siswa sudah pada tingkat mampu sudah tercapai. Oleh karenanya penelitian ini tidak dilanjutkan ke siklus berikutnya

\section{KESIMPULAN DAN SARAN}

Sehubungan dengan penerapan model pembelajaran Creative Problem Solving dalam proses pembelajaran yang telah dilakukan, serta hasil dari pelaksanaan tindakan seperti yang telah dijelaskan pada bab terdahulu telah memperoleh hasil sesuai harapan. Dari semua data yang telah diperoleh bahwa fakta-fakta yang ada telah mampu menjawab rumusan masalah dan tujuan penelitian ini. Bukti-bukti tersebut, dapat diuraikan sebagai berikut:

1) Pada awalnya nilai rata-rata siswa sebesar 66,94 dimana 3 siswa $(8,33 \%)$ memperoleh nilai di atas KKM, 13 siswa $(36,11 \%)$ memperoleh nilai sama dengan KKM sedangkan sisanya belum tuntas sebanyak 20 siswa $(55,56 \%)$.

2) Pada siklus I peroleh nilai rata-rata siswa sebesar 69,86 dimana 3 siswa $(8,33 \%)$ memperoleh nilai di atas KKM, 24 siswa $(66,67 \%)$ memperoleh nilai sama dengan KKM dan sisanya sebanyak 9 siswa (25\%) memperoleh nilai di bawah KKM. 
3) Pada siklus II rata-rata nilai siswa meningkat menjadi 81,22 dimana semua siswa sebanyak 36 orang sudah dinyatakan tuntas karena 28 siswa $(77,78 \%)$ memperoleh nilai di atas KKM, 8 siswa $(22,22 \%)$ memperoleh nilai sama dengan KKM.

Jadi dapat disimpulan bahwa dengan memaksimalkan penerapan model pembelajaran Creative Problem Solving dapat meningkatkan prestasi belajar Bahasa Bali siswa kelas X.IPA 8 semester II SMA Negeri 1 Kuta tahun pelajaran 2019/2020.

Mengacu pada kesimpulan yang telah dijelaskan, maka saran yang dapat disampaikan adalah: 1) Kepada teman guru pengajar mata pelajaran Bahasa Bali disarankan untuk meningkatkan keaktifan, kreativitas siswa dan keefektivan pembelajaran diharapkan menerapkan model pembelajaran model pembelajaran Creative Problem Solving untuk upaya meningkatkan prestasi belajar Bahasa Bali siswa. 2) Untuk memperoleh jawaban yang tepat, sesuai dengan tujuan penelitian disarankan untuk menggali pendapat atau tanggapan siswa dengan kalimat yang lebih mengarah pada proses pembelajaran dengan model pembelajaran model pembelajaran Creative Problem Solving. 3) Kepada kepala sekolah disarankan untuk memberi pemahaman agar guru mau melaksanakan pembelajaran dengan langkah-langkah model pembelajaran yang sudah diteliti. 4) Kepada pengawas agar membina guru-guru di wilayah binaannya agar mencoba model pembelajaran ini..

\section{UCAPAN TERIMAKASIH}

Ucapan terima kasih disampaikan kepada Kepala SMA Negeri 1 Kuta dan Bapak/Ibu Guru SMA Negeri 1 Kuta

\section{DAFTAR PUSTAKA}

Arikunto, Suharsimi; Suhardjono; Supardi. 2016. Penelitian Tindakan Kelas. Jakarta: PT Bumi Aksara.

Buchori, 2012. Artikel Hasil Penelitian. Pengaruh Model Pembelajaran Bahasa Bali Creative Problem Solving (CPS) Berbantuan Software GeogebraTerhadap Kemampuan Pemecahan Masalah Pada Siswa SMA. Fakultas Pendidikan Matematika Dan Ilmu Pengetahuan Alam. IKIP PGRI Semarang.

Darmawan, Deni. 2017. Komunikasi Pembelajaran Berbasis Brain Information Communication Technology. Penerbit: Humaniora. Bandung.

Depdiknas. 2013. Prestasi Belajar. Jakarta: Dirjen Pendidikan Dasar dan Menengah.

Idrus, Ali, 2015. Manajemen Pendidikan Global. Visi, Aksi \& Adaptasi. Penerbit: Gaung Persada Press. Jakarta.

Nur, Mohamad et al. 2013. Teori Belajar. Surabaya: University Press.

Purwanto, Ngalim. 2011. Psikologi Pendidikan. Bandung: Rosdakarya.

Rahman, B. 2017. Skripsi. Perbandingan Kemampuan Koneksi Matematik Siswa yang Pembelajarannya Menggunakan Model Creative Problem Solving (CPS) dengan Siswa yang Pembelajarannya Menggunakan Model Konvensional. FPMIPA UPI. Bandung.

Sardiman, A.M. (2013). Interaksi \& Motivasi Belajar Mengajar. Jakarta: PT. Raja Grafindo Perkasa

Slameto. 2013. Faktor-Faktor Yang Mempengaruhi Prestasi Belajar. Jakarta: Rineka Cipta.

Sugihartono, dkk.(2017). Psikologi Pendidikan. Yogyakarta: UNY Press

Supardi, Kasmadi Imam dan Putri, Indraspuri Rahning.Jurnal Inovasi Pendidikan Kimia, Vol . 4, No.1, 2014, hlm 574-581. Pengaruh Penggunaan Artikel Kimia 
Dari Internet Pada Model Pembelajaran Creative Problem Solving Terhadap Hasil Belajar Kimia Siswa SMA. Jurusan kimia FMIPA Universitas Negeri Semarang. Suryabrata, Sumadi. 2016. Psikologi Kepribadian. Jakarta : Raja Grafindo Persada.

Wardani, I. G. A. K. 2014. Modul IDIK 4307. Pemantapan Kemampuan Mengajar. Jakarta: Universitas Terbuka.

Wina Sanjaya. 2016. Strategi Pembelajaran Berorientasi Standar Proses Pendidikan. Kencana Prenada Media: Jakarta.

Winkel, W.S. 2013. Bimbingan dan Konseling di Institusi Pendidikan. Jakarta : Gramedia. 